\title{
Pengaruh Budaya Organisasi dan Gaya Kepemimpinan Terhadap Kepuasan Kerja dan Kinerja Pada PT Bank Riau Kepri Syariah Pekanbaru
}

\author{
Wenny Desty Febrian* \\ * Fakultas Ekonomi dan Ilmu Sosial, \\ Universitas Islam Negeri Sultan Syarif Kasim Riau \\ Jl. HR. Soebrantas Panam KM 15 No.155 Tampan Pekanbaru, 28293 \\ Email:wenny.sani27@gmail.com
}

\begin{abstract}
Abstrak: Salah satu perbankan syariah yang ada di Riau umumnya dan di Pekanbaru khususnya yaitu PT. Bank Riau Kepri Syariah. Secara resmi PT. Bank Riau Kepri Syariah Pekanbaru beroperasi di pusat kota Pekanbaru, yakni di Jl. Sudirman Pekanbaru. Dalam kegiatan usahanya PT. Bank Riau Kepri Syariah memiliki jenis simpanan seperti tabungan IB Sinar dan tabungan Umrah dan Haji. Secara parsial hasil penelitian ini terlihat nilai sig pada TBO adalah 0,130 . Nilai sig lebih besar dari nilai probabilitas 0,050, atau nilai $0,130>0,05$, maka $\mathrm{H}_{1}$ ditolak dan Ho diterima. Variabel $X_{1}$ mempunyai thitung yakni 1,529 dengan $t_{\text {tabel }}=1,989$. Jadi $t_{\text {hitung }}<t_{\text {tabel }}$ dapat disimpulkan bahwa variabel $\mathrm{X}_{1}$ tidak memiliki kontribusi terhadap $\mathrm{Y}$ atau TKK tidak berpengaruh signifikan terhadap TKI (Y). Untuk variabel Kepemimpinan ( $\left.\mathrm{X}_{2}\right)$ Terhadap Kinerja (Y) terlihat nilai sig pada TK adalah 0,000. Nilai sig lebih kecil dari nilai probabilitas 0,050, atau nilai $0,000<0,05$, maka $\mathrm{H}_{2}$ diterima dan Ho ditolak. Variabel $\mathrm{X}_{2}$ mempunyai thitung yakni 5,504 dengan $t_{\text {tabel }}=1,989$. Jadi thitung $>t_{\text {tabel }}$ dapat disimpulkan bahwa variabel $\mathrm{X}_{2}$ memiliki kontribusi terhadap $\mathrm{Y}$ atau TK berpengaruh signifikan terhadap TKI (Y). Untuk variabel Kepuasan Kerja (X) Terhadap Kinerja (Y) terlihat nilai sig pada TKK adalah 0,047. Nilai sig lebih kecil dari nilai probabilitas 0,050 , atau nilai $0,047<0,05$, maka $\mathrm{H}_{3}$ diterima dan Ho ditolak. Variabel $\mathrm{X}_{3}$ mempunyai thitung yakni 2,022 dengan tabel $=1,989$. Jadi thitung $>$ tabel dapat disimpulkan bahwa variabel $\mathrm{X}_{3}$ memiliki kontribusi terhadap Y atau TKK berpengaruh signifikan terhadap TKI (Y). Sedangkan secara simultan/keseluruhan nilai $F$ tabel dengan tingkat signifikan $\alpha=5 \%$ dan Degrees of Freedom (df) sebesar 3; 81 adalah sebesar 2,717. Dari tabel diperoleh nilai $F_{\text {hitung }}$ sebesar 25,294 dengan nilai probabilitas (sig)=0,000. Nilai $F_{\text {hitung }}(25,294)>F_{\text {tabel }}(2,717)$, dan nilai sig lebih kecil dari nilai probabilitas 0,05 atau nilai $0,000<0,05$ maka keputusan yang dapat diambil adalah Ho ditolak dan hipotesis penelitian diterima, berarti variabel TBO (X $\left.\mathrm{X}_{1}\right)$, TK ( $\left.\mathrm{X}_{2}\right)$, dan TKK $\left(\mathrm{X}_{3}\right)$, secara keseluruhan mempunyai pengaruh yang signifikan terhadap Variabel TKI (Y).
\end{abstract}

Kata Kunci : Budaya Organisasi, Gaya Kepemimpinan, Kepuasan Kerja, Kinerja 


\section{PENDAHULUAN}

Kontribusi karyawan pada suatu organisasi akan menentukan maju atau mundurnya organisasi. Kontribusi karyawan pada organisasi akan menjadi penting, jika dilakukan dengan tindakan efektif dan berperilaku secara benar. Tidak hanya jumlah usaha tetapi juga arah dari usaha. Sifat-sifat yang ada pada diri karyawan, upaya atau kemauan untuk bekerja, serta berbagai hal yang merupakan dukungan dari organisasi sangat besar artinya bagi keberhasilan kinerja karyawan (Suhardi Sigit, 2001). Dengan demikian setiap karyawan perlu mengetahui dengan pasti apa yang menjadi tanggung jawab utamanya, kinerja seperti apa yang harus dicapainya serta dapat mengukur sendiri sesuai indikator keberhasilannya. Banyak hal yang menjadi perhatian pihak manajemen guna mendorong kinerja karyawan diantaranya dalam kaitan budaya organisasi, gaya kepemimpinan dan kepuasan kerja bagi karyawannya. O’Reilly (1989), pada penelitian awal tentang norma pengukuran memperlihatkan dua karakteristik penting dari budaya yang kuat. Salah satunya adalah intensitasnya terhadap bagian anggota organisasi yakni menunjukkan persetujuan atau ketidaksetujuan terhadap mereka yang bertindak dengan cara tertentu, kedua adalah adanya kristalisasi atau kesepakatan yang luas terhadap nilai tersebut diantara anggota. Jika tidak ada kesepakatan bahwa serangkaian nilai yang terbatas penting dalam suatu unit sosial, budaya yang kuat tidak ada. Jika ada kesepakatan kuat dan meluas tentang arti penting nilai-nilai tertentu, sistem nilai sentral atau budaya kuat mungkin ada. Banyak penelitian telah menyimpulkan bahwa kesesuaian karyawan terhadap budaya organisasi meningkatkan komitmen, kepuasan, dan kinerja. Namun penelitian empiris terhadap hubungan ini yang telah dilakukan masih sedikit.

Kepemimpinan juga merupakan salah satu faktor penentu keberhasilan organisasi. Kepemimpinan mengalami pergeseran dari waktu ke waktu dan bersifat kontekstual yang dilatarbelakangi oleh perkembangan sosial, politik dan budaya yang berlaku pada jamannya. Dalam pendekatan situasional disadar bahwa tidak ada satupun gaya kepemimpinan yang terbaik dan berlaku universal untuk segala situasi dan lingkungan. Pengembangan penelitian oleh Bass (1985) dan Burn (1978) yang mengargumentasikan bahwa pemimpin transformasional dalam mencari pengikut yang memiliki kepercayaan dan kepekaan lebih tinggi terhadap pencapaian tujuan. Roueche, Baker, dan Rose (1989) menguji dan mengkategorikan kepemimpinan perguruan tinggi yang patut dicontoh menggunakan atribut perilaku transformasional. Menurut mereka menggunakan lima tema dalam analisis pemimpin yang transformatif, a. Dapat dipercaya dalam bekerja tim dan berbagi dalam pengambilan keputusan, b. Menilai orang berdasarkan mereka sebagai anggota tim dan sebagai individu, c. Memahami motivasi, d. Memiliki sistem penilaian personal yang kuat, e. Mempunyai visi mengenai perguruan tinggi mereka.

Selain budaya organisasi dan gaya kepemimpin, kepuasaan kerja sebagai bentuk reaksi yang dirasakan karyawan banyak mendapat perhatian dikalangan peneliti. Kepuasan kerja sangat penting artinya baik bagi karyawan maupun bagi perusahaan. Bidang ini sangat menarik perhatian para akademisi maupun para praktisi perusahaan. Kepuasan kerja 
merupakan salah satu bentuk perilaku kerja karyawan yang didefinisikan sebagai sesuatu yang menyenangkan atau sisi hasil emosional yang positif atas penilaian pekerjaan atau pengalaman kerja seseorang (Locke, 1969, dalam Vanderberg dan Lance, 1992). Kepuasan kerja ditentukan oleh perbedaan antara semua yang diharapkan dengan semua yang dirasakan dari pekerjaannya atau semua yang diterimanya secara aktual.
Salah satu perbankan syariah yang ada di Riau umumnya dan di Pekanbaru khususnya yaitu PT. Bank Riau Kepri Syariah. Secara resmi PT. Bank Riau Kepri Syariah Pekanbaru beroperasi di pusat kota Pekanbaru, yakni di Jl. Sudirman Pekanbaru. Dalam kegiatan usahanya PT. Bank Riau Kepri Syariah memiliki jenis simpanan seperti tabungan IB Sinar dan tabungan Umrah dan Haji.

Tabel 1: Karyawan bank Riau Kepri Syariah Pekanbaru Tahun 2016-2018

\begin{tabular}{|c|c|}
\hline Tahun & Jumlah Pegawai \\
\hline 2016 & 93 \\
2017 & 95 \\
2018 & 91 \\
\hline
\end{tabular}

Sumber : Bank Riau Kepri Syariah Pekanbaru, 2018

Sementara itu, untuk data jumlah Syariah Pekanbaru dapat dilihat dalam penabung pada PT. Bank Riau Kepri tabel sebagai berikut:

Tabel 2: Jumlah Nasabah PT. Bank Riau Kepri Syariah (Satuan Orang)

\begin{tabular}{|l|c|c|c|c|c|}
\hline \multicolumn{1}{|c|}{ Tabungan } & $\mathbf{2 0 1 4}$ & $\mathbf{2 0 1 5}$ & $\mathbf{2 0 1 6}$ & $\mathbf{2 0 1 7}$ & $\mathbf{2 0 1 8}$ \\
\hline \hline IB Sinar & 3.875 & 4.453 & 5.348 & 4.284 & 5.521 \\
\hline Umrah dan Haji & 2.989 & 1.961 & 1.389 & 1.499 & 1.828 \\
\hline Jumlah & $\mathbf{6 . 8 6 4}$ & $\mathbf{6 . 4 1 4}$ & $\mathbf{6 . 7 3 7}$ & $\mathbf{5 . 7 8 3}$ & $\mathbf{7 . 3 4 9}$ \\
\hline
\end{tabular}

Sumber :PT. Bank Riau Kepri Syariah Pekanbaru

Dari tabel diatas, dapat dilihat bahwa pada PT. Bank Riau Kepri Syariah Pekanbaru jumlah penabung pada produk tabungan $I B$ Sinar memiliki jumlah terbanyak dibandingkan dengan jenis tabungan yang lainnya, jenis tabungan ini mengalami peningkatan pada tahun 2014 dan 2015, namun mengalami penurunan pada tahun

\section{TINJAUAN PUSTAKA}

\section{Budaya Organisasi}

Budaya organisasi memiliki pengaruh yang signifikan terhadap bagaimana karyawan memandang organisasi mereka, tanggungjawab dan komitmen mereka.
2017 dan mengalami peningkatan lagi pada tahun 2018. Sementara untuk tabungan umrah dan haji jumlahnya lebih kecil dari pada tabungan IB Sinar, pada jenis tabungan ini jumlah penabung mengalami penurunan pada tahun 2015 dan 2016, kemudian mengalami peningkatan jumlah kembali pada tahun 2017 dan 2018.

Pemimpin mempengaruhi bawahan mereka baiksecara langsung melalui interaksi dan juga melalui budaya organisasi (Chen, 2004). Banyak definisi budayam organisasi, namun pada dasarnya definisi-definisi tersebut mengacu pada tiga 
pendekatan (Martin, 1992, dalam Andreas Budi Rahardjo, 2003), yaitu :

1. Integration approach, menyatakan bah wa setiap organisasi mempunyai satu jenis budaya yang mewarnai semua nilai dan kegiatan anggotanya. Pendekatan ini menekankan pada konsensus semua anggota organisasi terhadap satu budaya yang dominan.

2. Differentiation approach, menekankan pada konsensus sub budaya. Pada pendekatan ini dimungkinkan setiap organisasi mempunyai satu atau lebih sub budaya yang masih dapat dibedakan menjadi tiga yaitu sub budaya yang sejalan dan sama dengan budaya perusahaan, sub budaya yang berbeda dengan budaya perusahaan dan sub budaya yang berlawanan dengan budaya perusahaan.

3. Fragmentation approach, pada pendekatan ini tidak ada konsensus antar anggota organisasi dan tidak ada kesamaan atau kesepakatan nilainilai yang dianut pada anggota organisasi. Dengan kata lain budaya perusahaan tersebut tidak ada, yang ada nilai-nilai pribadi anggota organisasi.

Menurut Luthans (1998), budaya organisasi merupakan norma-norma dan nilai-nilai yang mengarahkan perilaku anggota organisasi. Setiap anggota akan berperilaku sesuai dengan budaya yang berlaku, agar diterima oleh lingkungannya. Robbins (2001), budaya organisasi mengacu ke suatu sistem makna bersama yang dianut oleh anggota-anggota yang membedakan organisasi itu dari organisasi yang lain. Sedangkan menurut Davis (1994), budaya organisasi adalah pola keyakinan dan nilai-nilai yang dipahami dan dijiwai (shared) oleh anggota organisasi sehingga pola tersebut memberikan makna tersendiri bagi organisasi bersangkutan dan menjadi dasar aturan berperilaku dalam organisasi (Achmad Sobirin, 2002). Pengertianpengertian di atas menunjukkan bahwa budaya organisasi adalah kebiasaan yang berlaku pada organisasi. Bisa jadi, dengan demikian antara satu organisasi dengan organisasi lainnya mempunyai kebiasaan yang berbeda meski keduanya bergerak pada bidang aktifitas yang sama. Kebiasaan-kebiasaan yang terjadi dalam sebuah organisasi tersebut sesungguhnya berasal dari nilai-nilai organisasi (organizational values). (Hofstede, 1997) atau nilai-nilai yang bersifat idealistik, karena merupakan elemen yang tidak tampak kepermukaan (hidden) dan hanya orang-orang organisasi saja yang tahu apa sesungguhnya ideologi mereka dan mengapa organisasi tersebut didirikan. Sebagai melemen yang tidak tampak dan bersifat idealistik sehingga merupakan inti dari budaya organisasi (core of culture).

Sedangkan elemen-elemen yang bersifat behavioral adalah elemen yang muncul kepermukaan dan tampak dalam perilaku sehari-hari para anggota organisasi. Oleh karena itu, bagi orang luar organisasi sering dianggap sebagai representasi dari budaya sebuah organisasi sebab mudah diamati, dipahami dan diinterpretasikan. Dengan mengamati bagaimana para anggota organisasi berperilaku dan kebiasaankebiasaan lain yang mereka lakukan, sebag ai bentuk praktek sehari-hari sebuah organisasi (Davis, 1984) atau kebiasaan tersebut muncul dalam bentuk praktekraktek manajemen, apakah sebuah organi sasi berorientasi pada proses atau hasil, karyawan atau pekerjaan, lebih parochial atau profesional, lebih terbuka atau 
tertutup, kontrol yang longgar atau kontrol yang ketat dan lebih normatif atau pragmatis (Hofstede et al. 1990). Elemen budaya organisasi yang bersifat artefak, adalah elemen yang paling luar, yang tampak dan berujud antara lain: desain bangunan, teknologi, bahasa, upacara, logo, dan sebagainya.

\section{Gaya Kepemimpinan}

Kepemimpinan merupakan salah satu faktor yang sangat penting bagi keberhasilan manajemen organisasi. Kepemimpinan yang efektif akan mampu mendorong motivasi anggota organisasi sehingga produktifitas, loyalitas dan kep asan bawahan atau anggota organisasi meningkat. Pada awalnya banyak yang berpendapat bahwa pemimpin itu dilahirkan, namun dengan berkembangnya pengetahuan diketahui bahwa terbentuknya kepemimpinan yang efektif dapat dipelajari. Kepemimpinan mengalami pergeseran dari waktu ke waktu dan bersifat kontekstual yang dilatarbelakangi oleh perkembangan sosial, politik dan budaya yang berlaku pada jamannya. Dalam pendekatan situasional disadari bahwa tidak Ada satupun gaya kepemimpinan yang terbaik dan berlaku universal untuk segala situasi dan lingkungan.

Pengertian tunggal tentang kepemimpinan masih belum ada kesepakatan diantara para ahli ilmu perilaku. Konsep kepemimpinan masih merupakan sesuatu yang ambigous (Pfeffer, 1977, dalam Payamta, 2002). Sedangkan Luthans (1995), menyatakan bahwa definisi kepemimpinan masih merupakan "black box" atau "unexplainable concept". Meskipun demikian, untuk memberikan sedikit pengertian tentang kepemimpinan, diantaranya menurut Hersey dan Blanchard (1985), kepemimpinan adalah suatu proses mempengaruhi kegiatankegiatan seseorang atau sekelompok orang dalam usaha mencapai suatu tujuan dalam situasi tertentu. Gibson, Ivancevich, dan Donnelley (1991), memberikan pengertian kepemimpinan (leadership) sebagai suatu upaya penggunaan jenis pengaruh bukan paksaan untuk memotivasi orang-orang mencapai tujuan tertentu. Dengan kata lain seorang leader adalah seseorang yang mempunyai daya untuk menarik orang lain dengan tanpa paksaan agar mereka secara bersama-sama mewujudkan visinya.

Hersey dan Blanchard (1982), mencoba mengatasi kelemahan teori sifat dan teori perilaku dengan mengembangkan pendekatan situasional. Mereka menyumbangkan "Cycle Theory of Leadership" yang bertolak dari siklus kehidupan manusia. Menurut studinya ditemukan bahwa gaya kepemimpinan cenderung berbeda beda dari situasi ke situasi yang lain. Untuk menerapkan gaya kepemimpinan yang efektif harus diawali dengan mendiagnosis situasi sebaikbaiknya. Diagnosis situasi berkaitan dengan kapan, tuntutan klim organisasi, harapan, kemampuan atasan dan bawahan. Pendekatan situasional menyarankan bahwa perilaku pemimpin yang efektif harus :

1. Selalu memperhatikan situasi yang di hadapi.

2. Memperlakukan bawahan sesuai deng an kebutuhan masing-masing.

Pemimpin penganut pendekatan situasion al cenderung berperilaku yang dapat diklasifikasikan menjadi :

1. Perilaku Direktif, leader bersifat me mberi pengarahan, perintah, petunju $\mathrm{k}$ yang berorientasi pada tugas. 
2. Perilaku Supportif, leader memberikan dukungan, motivasi, semangat kerja, pertimbanganpertimbangan manusiawi yang berorientasi pada perbaikan hubungan atasan bawahan.

Selanjutnya kedua perilaku ini dihubu ngkan dengan tingkat kematangan (maturity) bawahan. Maturity mengukurs ejauhmana bawahan mempunyai kemampuan dan kemauan melaksanakan tugas dengan baik dengan tanpa diawasi. Hubungan antara kedua jenis perilaku pimpinan dan kematangan bawahan menunjukkan empat jenis gaya kepemimpinan yang efektif untuk situasi tertentu. Ke empat gaya kepemimpinan tersebut adalah sebagai berikut :

1. Gaya Instruktif : leader cenderungm emberikan pengarahan (direktif)dan suportif yang rendah. Leader memberikan instruksi disertai pengawasan yang ketat. Gaya ini sesuai untuk menghadapi bawahan yang belum matang.

2. Gaya Konsultatif: leader memberikand irektif dan suportif yang tinggi. Setiap keputusan memperhatikan masukan bawahan yang telah matang.

3. GayaPartisipatif: leader memberikan suportif tinggi tetapi direktif yang rendah. Leader mengambil keputusan yang memperhatikan masukanmasukan bawahan. Gaya ini sesuai untuk menghadapi bawahan yang sudah agak matang.

4. Gaya Delegatif : leader memberikan direktif dan suportif yang rendah. Leader menyerahkan pengambilan keputusan dan pertanggungjawaban penuh pada bawahan. Gaya Delegatif hanya cocok untuk menghadapi bawahan yang benar-benar sudah matang.
Walaupun kepemimpinan adalah lebih banyak didiskripsikan dalam bentuk mengenai sebuah hubungan. Selain itu mengenai aturan dari pemimpin, aturan dari pengikut adalah juga diulas sebagai sesuatu yang penting bagi keberhasilan organisasi. Dalam penelitian ini dimensi gaya kepemimpinan mengacu pada dimensi yang dikembangkan Singh-Sengubta, Sunita

(1997) dalam Fuad Mas'ud (2004) yang terdiri dari :

1. Gaya Partisipatif (ParticipativeS tyle)

2. Gaya Birokratis (Bureaucratic Style)

3. Gaya Pengasuh (Nurturant Style)

4. Gaya Berorientasi Tugas (Task)

5. Gaya Otoriter (Authoritarian Style)

6. Oriented Style

\section{Kepuasan Kerja}

Karyawan yang bekerja dalam keada an terpaksa akan memiliki hasil kerja (performance) yang buruk dibanding dengan karyawan yang bekerja dengan semangat tinggi. Apabila perusahaan memiliki karyawan yang mayoritas kepuasannya rendah, dapat berpengaruh terhadap tingkat produktifitas perusahaan secara keseluruhan menurun, dalam hal ini akan merugikan perusahaan.

Kepuasan kerja memiliki hubungan langsung dengan positive behavior pada pekerjaan. Menurutnya karyawan yang memiliki kepuasan tinggi maka tingkat performance tinggi dari pada karyawan yang kepuasannya rendah. Hubungan antara perusahaan dengan karyawan adalah hubungan yang saling menguntungkan. Di satu sisi perusahaan ingin mendapatkan keuntungan yang 
besar, disisi lain karyawan menginginkan harapan dan kebutuhan tertentu yang harus dipenuhi perusahaan, oleh karena itu SDM sebagai aset yang berharga, perusahaan harus memperhatikan aspekaspek yang dapat memunculkan rasa aman dan kepuasan karyawan terhadap pekerjannya atau yang sering disebut dengan kepuasan kerja (Job Satisfaction). Banyak pengertian yang dikemukakan para ahli tentang kepuasan kerja, dan asing-masing ahli memberikan batasanbatasan tersendiri dari kepuasan tersebut. Diantaranya menurut Robbins (1998), mengemukakan bahwa kepuasan kerja adalah sikap umum seseorang terhadap pekerjaannya. Seseorang dengan tingkat kepuasan yang tinggi menunjukkan sikap yang positif terhadap kerjanya, sedangkan yang tidak puas dengan pekerjaannya menunjukkan sikap yang negatif terhadap pekerjaannya.

Ada dimensi tentang kepuasan kerja menurut Luthans (1995) adalah sebagai berikut :

a. Kepuasan kerja adalah merupakan suatu emosi yang merupakan respon terhadap situasi kerja sehingga kepuasan kerja tidak dapat dilihat namun bisa dirasakan dan akan tercermin dalam sikap.

b. Kepuasan kerja dalam hasil yang sesuai atau bahkan melebihi yang diharapkan, seperti seseorang yang bekerja sebaik yang mampu dilakukan dan bersikap mendapat imbalan yang sepadan

c. Kepuasan kerja biasanya dinyatakan dalam sikap, seperti semakin loyal dalam perusahaan, bekerja dengan baik, berdedikasi tinggi pada perusahaan, tertib dan mematuhi peraturan dan sikap lain yang bersifat positif.
Ada beberapa faktor dalam organisasi yang dapat mempengaruhi kepuasan kerja, menurut Locke (1976) dalam Robbins (1998) adalah :

a. Kerja yang secara mental menantang. Karyawan lebih cenderung menyukai pekerjaan yang memberikan mereka kesempatan untuk menggunakan ketrampilan dan kemampuan mereka dan menawarkan beragam tugas kebebasan dan umpan balik mengenai betapa baik mereka bekerja.

b. Ganjaran yang pantas.

Karyawan cenderung menginginkan sistem upah dan kebijakan promosi yang mereka persepsikan sebagai adil, tidak meragukan dan segaris dengan pengharapan mereka. Jika upah dilihat sebagai adil yang didasarkan pada tuntutan pekerjaan, tingkat ketrampilan individu dan standar pengupahan komunitas, kemungkinan besar akan memberikan kepuasan.

c. Kondisi kerja yang mendukung. Lingkungan kerja yang baik akan memberikan kenyamanan pribadi maupun untuk memudahkan mengerjakan tugas yang baik.

d. Rekan kerja yang mendukung. Bagi kebanyakan karyawan, interaksi sosial dibutuhkan. Oleh karena itu mempunyai rekan kerja yang ramah dan mendukung, menghantarkan kepada kepuasan yang meningkat.

e. Kesesuaian kepribadian dengan pekerj aan. Kecocokan yang tinggi antara kepribadian seseorang karyawan dan pekerjaan akan menghasilkan individu yang lebih terpuaskan.

Hubungan antara bawahan dengan pihak pimpinan sangat penting artinya dalam meningkatkan produktifitas kerja terhadap kerja dapat ditingkatkan melalui perhatian dan hubungan yang 
baik dari pimpinan kepada bawahan, sehingga karyawan akan merasa bahwa dirinya merupakan bagian yang penting dari organisasi tempat bekerja (Celluci dan De Fries, 1979, dalam Fuad Mas'ud, 2004). Kepuasan kerja merupakan faktor penentu bagi sikap karyawan terhadap pekerjaannya. Bila pekerjaan itu menyenangkan dan sesuai dengan keinginan karyawan maka kepuasan kerja karyawan terpenuhi. Jika faktor tersebut dirasakan kurang atau tidak diberikan maka karyawan akan merasa tidak puas, akan banyak mengeluh, dan jika karyawan merasakan faktor-faktor yang ada terpenuhi, maka kepuasan kerja ada dengan sendirinya. Indikator-indikator kepuasan kerja dalam penelitian ini mengacu pada rumusan Celluci dan De Fries, (1979) dalam Fuad Mas'ud (2004), adalah sebagai berikut:
a. Kepuasan dengan gaji.
b. Kepuasan dengan penyelia.
c. Kepuasan dengan promosi
d. Kepuasan dengan pekerjaan itu
e. Kepuasan dengan rekan kerja sendiri.

\section{Budaya Organisasi dan Kinerja Karyawan}

Tahun

$$
\text { 1980-an }
$$

memberikan kesaksian mengenai gelombang popularitas Untuk menguji konsep budaya organisasi sebagai manajer menjadi meningkatkan Kesadaran akan jalan dimana budaya organisasi dapat mempengaruhi karyawan dan organisasi (Daulatram,2003). Perembesan budaya organisasi membutuhkan pengenalan manajemen dimensi dasar dari budayaor ganisasi mereka dan pengaruhnya pada varibel yang berkaitan dengan karyawan seperti kepuasan, komitmen, kohesi, implementasi strategi, kinerja dan yang lain.
Bagi Denison (1990), dan Kotter dan Heskett (1992), perusahaan yang berhasil bukan sekedar mempunyai budaya yang kuat akan tetapi budaya yang kuat tersebut harus cocok dengan lingkungannya. O'Reilly, Chatman dan Cadwell (1991) dalam penelitiannya bahwa budaya perusahaan mempunyai pengaruh terhadap efektifitas perusahaan, terutama pada perusahaan yang mempunyai budaya yang sesuai dengan strategi dan dapat meningkatkan komitmen karyawan terhadap perusahaan.

Survei yang dilakukan Sheridan, menunjukkan bahwa budaya organisasi secara signifikan berhubungan positif dengan kinerja karyawan, voluntary turnover dan komitmen organisasi. Dikatakan bahwa variasi dalam cultural value memiliki pengaruh terhadap tingkat turnover dan kinerja karyawan.

\section{Gaya Kepemimpinan dan Kinerja Karyawan}

Kepemimpinan pada dasarnya adalah proses mempengaruhi orang lain. Selain itu, kepemimpinan biasanya juga berarti kemampuan untuk mempengaruhi, menggerakkan, dan mengarahkan suatu tindakan pada diri seseorang atau sekelompok orang untuk tujuan tertentu. Dalam organisasi kemampuan untuk mempengaruhi, mendesak dan mendorong pengikutnya didasarkan pada kekuasaan yang dimiliki oleh seorang pemimpin. Keefektifan seorang pemimpin dalam mempengaruhi orang lain sangat ditentukan oleh seberapa jauh seseorang mempunyai kekuasaan. Semakin banyak kekuasaan, maka akan semakin mudah seseorang untuk mempengaruhi orang lain. Akan tetapi dengan kekuasaan yang banyak seseorangtidak secara otomatis dapat 
memimpin organisasi dengan efektif. Hal ini sangat tergantung banyak faktor antara lain kemampuan pemimpin, kemampuan bawahan dan lingkungan.

\section{Penilaian Kinerja}

Teknik paling tua yang digunakan oleh manajemen untuk meningkatkan kinerja adalah penilaian (appraisal). Motivasi karyawan untuk bekerja, mengembangkan kemampuan pribadi, oleh meningkatkan kemampuan di masa rnendatang dipengaruhi oleh umpan balik mengenai kinerja masa lalu dan pengembangan. Penilaian kinerja (performance appraisal) adalah proses organisasi dalam mengevaluasi pelaksanaan kerja karyawan. Dalam penilaian kinerja dinilai kontribusi karyawan kepada organisasi selama periode waktu tertentu. Umpan balik kinerja memungkinkan karyawan rnengetahui seberapa baik kinerja jika dibandingkan dengan setandar organisasi. Apabila penilaian kinerja dilakukan secara benar, para karyawan , penyelia, departemen SDM, dan akhirnya organisasi akan diuntungkan dengan melalur upayaupaya karyawan memberikan kontribusi kepada organisasi.

Penilaian kinerja secara keseluruhan merupakan proses yang berbeda dari evaluasi pekerjaan (job evaluation). Penilaian kinerja berkenaan dengan seberapa baik seseorang melakukan pekerjaan yang ditugaskannya. Evaluasi pekerjaan menentukan seberapa tinggi harga sebuah pekerjaan bagi organisasi, dengan demikian kisaran berapa gaji yang layak diberikan untuk pekerjaantersebut. Sementara penilaian kinerja menunjukkan bahwa seseorang adalah pemogram komputer yang organisasi, evaluasi pekerjaan digunakan untuk memastikan bahwa pemrogram tersebut menerima gaji maksimal untuk posisi programmer komputer sesuai dengan posisi tersebut bagi organisasi.

\section{METODE}

Jenis data yang digunakan dalam pe nelitian ini terdiri dari Data Primer, yaitu data yang diperoleh secara langsung dari sumbernya, terdiri dari :

Bagian pertama : Berisi data responden yaitu jenis kelamin, lama bekerja, umur, jabatan, dan pendidikan.

Bagian kedua : Data yang berkaitan dengan budaya organisasi, gaya kepemimpinan, kepuasan kerja, dan kinerja karyawan.

Data Sekunder yaitu data yang diperol eh secara tidak langsung dari sumbernya, yang terdiri dari gambaran umum karyawan/pegawai dan bagianbagian yang ada di Bank Riau Kepri Syariah Pekanbaru.

Sebagai populasi dalam penelitian ini adalah seluruh pegawai yang bekerja pada Bank Riau Kepri Syariah Pekanbaru 2014-2018. Dalam penelitian ini seluruh karyawan administratif dalam populasi sebagai anggota sampel, mengenai sampel yang representatif untuk digunakan dalam teknik analisis SPSS.

Metode pengumpulan data dalam penelitian ini dilakukan dengan menggunakan Metode kuesioner (dafar pernyataan). Kuesioner yang telah disusun, merupakan rangkaian-rangkaian pertanyaan yang berkaitan dengan budaya organisasi, gaya kepemimpinan dan kinerja karyawan. Kuesioner tersebut dibedakan menjadi kuesioner tertutup yaitu responden hanya diberi kesempatan untuk memilih jawaban yang telah disediakan 
sesuai dengan pendapatnya, dan kuesioner terbuka yaitu responden diberi kesempatan untuk menjawab sesuai dengan pendapatnya secara bebas.

Pernyataan-pernyataan dalam kuesioner tersebut disertai jawaban dengan menggunakan skala liker yang mana :

SS : Sangat Setuju (Skala 4)

$S$ : Setuju (Skala 3)

TS : Tidak Setuju (Skala 2)

STS: Sangat Tidak Setuju (Skala 1)

Data-data dari kuesioner tersebut nantinya akan diinput kedalam SPSS dan diolah.
HASIL

\section{Uji Hipotesis Parsial (Uji T)}

Uji t digunakan untuk mengetahui apakah variabel-variabel independen secara parsial berpengaruh nyata atau tidak terhadap variabel dependen. Derajat signifikansi yang digunakan adalah 0,05. Apabila nilai signifikan lebih kecil dari derajat kepercayaan maka kita menerima hipotesis alternatif, yang menyatakan bahwa suatu variabel independen secara parsial mempengaruhi variabel dependen.

\section{Tabel 3: Hasil Uji Hipotesis parsial (Uji T)}

\section{Coefficients ${ }^{\mathrm{a}}$}

\begin{tabular}{|c|c|c|c|c|c|c|}
\hline & & \multicolumn{2}{|c|}{$\begin{array}{l}\text { Unstandardized } \\
\text { Coefficients }\end{array}$} & \multirow{2}{*}{\begin{tabular}{|l}
$\begin{array}{l}\text { Standardized } \\
\text { Coefficients }\end{array}$ \\
Beta
\end{tabular}} & \multirow[b]{2}{*}{$\mathrm{T}$} & \multirow[b]{2}{*}{ Sig. } \\
\hline \multicolumn{2}{|c|}{ Model } & B & Std. Error & & & \\
\hline 1 & (Constant) & 4.799 & 3.300 & & 1.454 & .150 \\
\hline & TBO & .180 & .117 & .145 & 1.529 & .130 \\
\hline & TK & .522 & .095 & .518 & 5.504 & .000 \\
\hline & TKK & .184 & .091 & .179 & 2.022 & .047 \\
\hline
\end{tabular}

a. Dependent Variable: TKI

1) TBO $\left(\mathrm{X}_{1}\right)$ Terhadap TKI $(\mathrm{Y})$

Terlihat nilai sig pada TBO adalah 0,130 . Nilai sig lebih besar dari nilai probabilitas 0,050 , atau nilai $0,130>0,05$, maka $\mathrm{H}_{1}$ ditolak dan Ho diterima. Variabel $\mathrm{X}_{1}$ mempunyai $t_{\text {thitung }}$ yakni 1,529 dengan $t_{\text {tabel }}=1,989$. Jadi thitung $<$ tabel dapat disimpulkan bahwa variabel $\mathrm{X}_{1}$ tidak memiliki kontribusi terhadap Y atau TKK tidak berpengaruh signifikan terhadap TKI (Y).

2) TK $\left(X_{2}\right)$ Terhadap TKI (Y)

Terlihat nilai sig pada TK adalah 0,000 . Nilai sig lebih kecil dari nilai probabilitas 0,050, atau nilai $0,000<$ 0,05, maka $\mathrm{H}_{2}$ diterima dan $\mathrm{Ho}$ ditolak. Variabel $\mathrm{X}_{2}$ mempunyai thitung yakni 5,504 dengan tabel=1,989. Jadi thitung $>$ tabel dapat disimpulkan bahwa variabel $\mathrm{X}_{2}$ memiliki kontribusi terhadap $\mathrm{Y}$ atau TK berpengaruh signifikan terhadap TKI (Y).

3) TKK $\left(\mathrm{X}_{3}\right)$ Terhadap TKI (Y)

Terlihat nilai sig pada TKK adalah 0,047 . Nilai sig lebih kecil dari nilai probabilitas 0,050 , atau nilai $0,047<0,05$, maka $\mathrm{H}_{3}$ diterima dan Ho ditolak. Variabel $\mathrm{X}_{3}$ mempunyai thitung yakni 2,022 dengan $t_{\text {tabel }}=1,989$. Jadi $t_{\text {hitung }}>t_{\text {tabel }}$ dapat disimpulkan bahwa variabel $\mathrm{X}_{3}$ memiliki kontribusi terhadap $\mathrm{Y}$ atau TKK berpengaruh signifikan terhadap TKI (Y). 


\section{Hasil Pengujian Hipotesis}

Tabel 4: Hasil Uji Hipotesis

\begin{tabular}{|l|l|l|l|l|}
\hline Hipotesis & $\begin{array}{l}\text { Perbandingan } \\
\text { variabel thitung } \\
\text { dan ttabel }\end{array}$ & $\begin{array}{l}\text { Perbandingan } \\
\text { Nilai Sig dan } \\
\text { Probabilitas }\end{array}$ & Pernyataan & Keterangan \\
\hline $\begin{array}{l}\mathrm{H}_{1} \\
\left(\mathrm{X}_{1} \text { terhadap } \mathrm{Y}\right)\end{array}$ & $1,529<1,989$ & $0,130>0,05$ & $\begin{array}{l}\text { Variable TBO tidak } \\
\text { berpengaruh signifikan } \\
\text { terhadap TKI }\end{array}$ & $\begin{array}{l}\mathrm{H}_{1} \text { ditolak } \\
\mathrm{H}_{0} \text { diterima }\end{array}$ \\
\hline $\begin{array}{l}\mathrm{H}_{2} \\
\left(\mathrm{X}_{2} \text { terhadap } \mathrm{Y}\right)\end{array}$ & $5,504>1,989$ & $0,000<0,05$ & $\begin{array}{l}\text { Variable } \\
\text { berpengaruh signifikan } \\
\text { terhadap TKI }\end{array}$ & $\begin{array}{l}\mathrm{H}_{2} \text { diterima } \\
\mathrm{H}_{0} \text { ditolak }\end{array}$ \\
\hline $\begin{array}{l}\mathrm{H}_{3} \\
\left(\mathrm{X}_{3} \text { terhadap } \mathrm{Y}\right)\end{array}$ & $2,022>1,989$ & $0,047<0,05$ & $\begin{array}{l}\text { Variable } \\
\text { berpengaruh signifikan } \\
\text { terhadap TKI }\end{array}$ & $\begin{array}{l}\mathrm{H}_{3} \text { diterima } \\
\mathrm{H}_{0} \text { ditolak }\end{array}$ \\
\hline
\end{tabular}

digunakan adalah 0,05. Apabila nilai $\mathrm{F}$ hasil perhitungan lebih besar daripada nilai $\mathrm{F}$

\section{Uji Hipotesis Serempak (Uji F)}

Uji $F$ digunakan untuk mengetahui apakah variabel-variabel independen secara simultan berpengaruh signifikan terhadap variabel dependen. Uji ini membandingkan nilai $\mathrm{F}$ hitung dengan nilai F tabel, dan derajat kepercayaan yang menurut tabel maka hipotesis alternatif, yang menyatakan bahwa semua variabel independen secara simultan berpengaruh signifikan terhadap variabel dependen. Nilai $F$ hitung dapat dilihat pada Tabel ANOVA berikut ini :

ANOVA $^{b}$

Tabel 5: Hasil Uji Hipotesis Serempak (Uji F)

\begin{tabular}{|c|c|c|c|c|c|c|}
\hline \multicolumn{2}{|c|}{ Model } & $\begin{array}{l}\text { Sum } \\
\text { Squares }\end{array}$ & $\mathrm{Df}$ & Mean Square & $\mathrm{F}$ & Sig. \\
\hline \multirow[t]{3}{*}{1} & Regression & 818.029 & 3 & 272.676 & 25.294 & $.000^{\mathrm{a}}$ \\
\hline & Residual & 873.218 & 81 & 10.780 & & \\
\hline & Total & 1691.247 & 84 & & & \\
\hline
\end{tabular}

a. Predictors: (Constant), TKK, TK, TBO

b. Dependent Variable: TKI

Pengujian secar simultan $\mathrm{X}_{1}, \mathrm{X}_{2}$, dan $\mathrm{X}_{3}$ terhadap Y:

Nilai $\mathrm{F}$ tabel dengan tingkat signifikan $\alpha=$ 5\% dan Degrees of Freedom (df) sebesar 3; 81 adalah sebesar 2,717. Dari tabel diperoleh nilai Fhitung sebesar 25,294 dengan nilai probabilitas (sig) $=0,000$. Nilai Fhitung $(25,294)>F_{\text {tabel }}(2,717)$, dan nilai sig lebih kecil dari nilai probabilitas 0,05 atau nilai $0,000<0,05$ maka keputusan yang dapat diambil adalah Ho ditolak dan hipotesis penelitian diterima, berarti variabel TBO $\left(\mathrm{X}_{1}\right)$, TK $\left(\mathrm{X}_{2}\right)$, dan TKK $\left(\mathrm{X}_{3}\right)$, secara keseluruhan mempunyai pengaruh yang signifikan terhadap Variabel TKI (Y). 


\section{SIMPULAN}

Secara parsial hasil penelitian ini dapat dijelaskan sebagai berikut :

1) Budaya Organisasi ( $\left.X_{1}\right)$ Terhadap Kinerja (Y)

Terlihat nilai sig pada TBO adalah 0,130 . Nilai sig lebih besar dari nilai probabilitas 0,050 , atau nilai $0,130>0,05$, maka $\mathrm{H}_{1}$ ditolak dan Ho diterima. Variabel $\mathrm{X}_{1}$ mempunyai thitung yakni 1,529 dengan tabel=1,989. Jadi thitung $<$ tabel dapat disimpulkan bahwa variabel $\mathrm{X}_{1}$ tidak memiliki kontribusi terhadap Y atau TKK tidak berpengaruh signifikan terhadap TKI (Y).

2) Kepemimpinan $\left(\mathrm{X}_{2}\right)$ Terhadap Kinerja (Y)

Terlihat nilai sig pada TK adalah 0,000 . Nilai sig lebih kecil dari nilai probabilitas 0,050 , atau nilai $0,000<$ 0,05, maka $\mathrm{H}_{2}$ diterima dan $\mathrm{Ho}$ ditolak. Variabel $\mathrm{X}_{2}$ mempunyai thitung yakni 5,504 dengan tabel $=1,989$. Jadi $t_{\text {thitung }}>$ ttabel dapat disimpulkan bahwa variabel $\mathrm{X}_{2}$ memiliki kontribusi terhadap $\mathrm{Y}$ atau TK berpengaruh signifikan terhadap TKI (Y).

3) Kepuasan Kerja ( $\left.X_{3}\right)$ Terhadap Kinerja (Y)

Terlihat nilai sig pada TKK adalah 0,047. Nilai sig lebih kecil dari nilai probabilitas 0,050 , atau nilai $0,047<0,05$, maka $\mathrm{H}_{3}$ diterima dan Ho ditolak. Variabel $\mathrm{X}_{3}$ mempunyai thitung yakni 2,022 dengan ttabel $=1,989$. Jadi thitung $>$ tabel dapat disimpulkan bahwa variabel $\mathrm{X}_{3}$ memiliki kontribusi terhadap $\mathrm{Y}$ atau TKK berpengaruh signifikan terhadap TKI (Y).

Sedangkan

secara simultan/keseluruhan nilai $\mathrm{F}$ tabel dengan tingkat signifikan $\alpha=5 \%$ dan Degrees of
Freedom (df) sebesar 3; 81 adalah sebesar 2,717. Dari tabel diperoleh nilai $F_{\text {hitung }}$ sebesar 25,294 dengan nilai probabilitas (sig) $=0,000$. Nilai $F_{\text {hitung }}(25,294)>F_{\text {tabel }}$ $(2,717)$, dan nilai sig lebih kecil dari nilai probabilitas 0,05 atau nilai 0,000 $<0,05$ maka keputusan yang dapat diambil adalah Ho ditolak dan hipotesis penelitian diterima, berarti variabel TBO $\left(\mathrm{X}_{1}\right)$, TK $\left(\mathrm{X}_{2}\right)$, dan TKK $\left(\mathrm{X}_{3}\right)$, secara keseluruhan mempunyai pengaruh yang signifikan terhadap Variabel TKI (Y).

\section{DAFTAR RUJUKAN}

Achmad Sobirin, "Budaya : Sumber Kekuatan Sekaligus Kelemahan Organisasi". Jurnal Siasat Bisnis, No.7, Vol. 1, Hal. 1-20. 2002.

Arif, Muhammad. 2018. Analisis Rekrutmen dan Penempatan Kerja terhadap Kinerja Karyawan pada Hotel Oase. Jurnal Al-Hikmah: Vol. 15 (1): 42-63.

Arif, M. (2019). The Effect of Managerial Competencies, Compesation and Career Planning Toward Employee Performance Through Job Satisfaction at PT. Bank BTPN Tbk Mikro Banking Division (MUR) Pekanbaru Branch. Journal of Management Info, 6(1), 1721.

Andreas Budihardjo, "Peranan Budaya Perusahaan : Suatu Pendekatan Sistematik dalam Mengelola Perusahaan". Jurnal Manajemen Prasetya Mulya, Mei, Vol. VIII, No. 14. 2003

Burns J. M., Leadership, New York: Harper \& Row. 1978

Daulatram B. Lund, "Organizational Culture ang Job Satisfaction", Journal of Business and Industrial Marketing, Vol. 18, No. 3. 2003

Davis S., Managing Corporate Culture, Cambridge, MA: Belinger. 1984 
Denison, Cooporate Culture and Organizational Effectiveness, New York, Willey. 1990

Fuad Mas'ud, Survai Diagnosis Organisasional : Konsep dan Aplikasi, Badan Penerbit UNDIP, Semarang. 2004

Gibson J. H., Ivancevich J. M. \& Donnally Jr. J. H., Organization: Behaviour, Stucture, Processes, Homeword III: Richard D. Irwin, Inc. Golberg C.B., dan Waldman D.A., 2000,"Modelling Employee Absenteeism : Testing Alternative Measures Medating Effecs Based on Job Satisfaction", Journal of Organizational Behavior, 21 (6) : 665676,1991

Hersey P, \& Blachard K. H., "Life Cycle Theory of Leadership", Training and Development Journal, 23(2), 26-34, 1969

Hofstede G., Neuijen B., Ohayu D. dan Sander G., "Measuring Organizational Cultures: A Qualitative Study Across Twenty Cases", Adminitrative Science Quarterly, 35 : $285-316$, 1990

Locke E. A., "Job Satisfaction and Job Performance: a Theorytical Analysis", Organization Behavior and Human Performance, Vol.5, p.484-500, 1970

Luthans F., Organizational Behavioural, 7th Edition, McGraw-Hill, New York, 1992

Martin J., Cultures in Organizations: Three Perspective, Oxford University Press, London, 1992

O' Reilly III C. A., Chatman J. Caldwell D. F., "People and Organizational Culture: A Profile Comparison Approach to Assesing Person - Organization Fit", Academy of Management Journal, Vol. 34, 3, p.487-516, 1991
Payamta, "Gaya Kepemimpinan : Perkembangan dan Kepemimpinan Dalam Era Global", Telaah September No. 13, 2003

Peterson D. E., \& J. Hillkirk, A Better Idea: Redefining The Way American Companies Work, Boston: Houghton-Mifflin, 1941

Petty M. M, G. W. McGee, \& J. W. Cavender, "A Meta-Analysis of The Relationship between Individual Performance", Academy of Management Review 9(4): 712-21, 1984

Robbins S. P., Perilaku Organisasi : Konsep, Kontroversi, Aplikasi, edisi kedelapan versi Bahasa Indonesia, Jilid 1 \& 2, PT Prenhallindo, Jakarta. Roueche J. E. Baker G. A. III, \& Rose R. R., 1989 